\title{
Death Blow to Jim Crow: The National Negro Congress and the Rise of Militant Civil Rights. By Erik S. Gellman. (Chapel Hill, NC: University of North Carolina Press, 2012. Pp. xiii, 354. \$39.95.)
}

Christopher E. Manning

Loyola University Chicago, cmannin@luc.edu

Follow this and additional works at: https://ecommons.luc.edu/history_facpubs

Part of the History Commons

Author Manuscript

This is a pre-publication author manuscript of the final, published article.

\section{Recommended Citation}

Manning, Christopher E.. Death Blow to Jim Crow: The National Negro Congress and the Rise of Militant Civil Rights. By Erik S. Gellman. (Chapel Hill, NC: University of North Carolina Press, 2012. Pp. xiii, 354. \$39.95.). The Historian, 76, 1: , 2014. Retrieved from Loyola eCommons, History: Faculty Publications and Other Works, http://dx.doi.org/10.1111/hisn.12030_18

This Book Review is brought to you for free and open access by the Faculty Publications and Other Works by Department at Loyola eCommons. It has been accepted for inclusion in History: Faculty Publications and Other Works by an authorized administrator of Loyola eCommons. For more information, please contact ecommons@luc.edu.

\section{(c) $($ () $\ominus$}

This work is licensed under a Creative Commons Attribution-Noncommercial-No Derivative Works 3.0 License. (C) 2014 Phi Alpha Theta 


\section{Biographical Citation}

Christopher Manning is an associate professor of history at Loyola University Chicago and author of William L. Dawson and the Limits of Black Electoral Leadership (Northern Illinois University Press, 2009). He received his Ph.D. from Northwestern University in 2003 and is currently working on a project provisionally titled NOLA: An Oral History of the Hurricane Katrina Volunteers. 
Death Blow to Jim Crow: The National Negro Congress and the Rise of Militant Civil Rights. By Eric S. Gellman. (Chapel Hill, North Carolina: University of North Carolina Press, 2012. Pp. xiii, 354. \$39.95.)

In Death Blow to Jim Crow Eric Gellman argues that the National Negro Congress played a leading role in the late 1930s through mid-1940s era Popular Front: a coalition, of labor, civil rights leaders, and liberals who fought to expand New Deal reforms and rebuff fascism. (4). Moreover, the NNC moved away from established civil rights groups by envisioning race as a material rather than a moral issue and as national rather than southern in scope (4-5).

Gellman contends that the New Deal brought new government receptivity to African American issues (9). Simultaneously A. Phillip Randolph's Brotherhood of Sleeping Car Porters and the Communist Party's defense of the Scottsboro boys drew attention to connections between civil rights and labor issues, while engaging the curiosity of college-educated African Americans who sought new civil rights strategies (11-12). These trend lines met in 1935 with the founding of the National Negro Congress, a coalition of activists who articulated a class and race based agenda (16). 
Gellman then analyzes the NNC's early efforts to move thousands of blacks into unions as part of a plan to leverage their power in labor (20-21). He argues that this plan had effects in Chicago, with more Chicago blacks moving into unions even though national level union leaders did not enact democratic programs.

Gellman shifts his examination to the NNC's youth affiliate, the Southern Negro Youth Congress (SNYC), and its collaboration with the Tobacco Stemmers and Laborers Union in Richmond, Virginia. This organization drive failed, he contends, but it set the precedent for interracial industrial unionism across the South (63-66, 103-107).

Moving back to the main organization, Gellman focuses on A. Phillip Randolph's split from the NNC in 1940. Randolph's withdrawal shocked some contemporaries, but others argued that it made the NNC more streamlined for the Civil Rights fight. Gellman asserts that despite Randolph's departure, his later successes derived from the NNC's earlier activism (150-158, 162).

Gellman then tracks the NNC's struggles through the war years. The war prevented the NNC from using the tactics it employed in the 1930s. A new generation of female leaders, however, took the helm, focusing the group on education, creating alliances with unions, and campaigning to keep the NNC at the forefront of civil rights (164-166). 
Gellman finishes with another analysis of the Southern Negro Youth Congress (SNYC) and argues that SNYC linked a domestic civil rights agenda to an international campaign against fascism. Members of SNYC, for example, played key roles in the formation of the South Carolina Progressive Democratic Party, which challenged the nomination of segregationist Senator Jimmy Byrnes to the vice presidency in 1944 (216-222). When they returned to South Carolina they connected to other international youth organizations and utilized Communist Party analysis to critique domestic and international politics.

This utilization of Communist analysis, however, lead to a disavowal of the NNC as the Cold War rendered such connections untenable. Fortunately, Gellman's work has returned the NNC to its proper place within our understanding of the Long Civil Rights Movement.

Loyola University Chicago Christopher Manning 